DOI : https://doi.org/10.24123/jbt.v5i2.4097

\title{
PENGARUH PARTISIPASI PENYUSUNAN ANGGARAN DAN BUDAYA ORGANISASI TERHADAP KINERJA MANAJERIAL PADA PT PERKEBUNAN NUSANTARA VIII
}

\author{
Rahmat Saleh $^{1}$, Lili Dahliani ${ }^{2}$, Rifa Rusiva ${ }^{3}$ \\ ${ }^{1,2,3}$ Sekolah Vokasi IPB; Bogor, Indonesia \\ Email : rahmat_saleh@apps.ipb.ac.id ${ }^{1}$, leogirlteteh@gmail.com², \\ rifarusiva@apps.ipb.ac.id ${ }^{3}$
}

\begin{abstract}
PT Perkebunan Nusantara VIII is a state-owned plantation engaged in the Agribusiness and Agro-Industry sectors. The budget preparation process that involves subordinates can improve the performance of subordinates in achieving budget targets. Participatory budgets can be carried out to achieve budget targets by negotiating between superiors and subordinates. In addition to being measured by employees and the cultural linkages attached to them, organizational success can also be seen from the overall performance of the organization. The purpose of this study was to examine the effect of budgetary participation and organizational culture on managerial performance. The total population of this study was 23 PTPN VIII tea gardens in West Java. Respondents in this study were garden managers, assistant heads, assistants, and large foremen of PTPN VIII (Persero) who were involved in the participation process (proposing and or implementing) the budget with a total sample of 63 respondents selected through purposive sampling. testing the quality of the data used is the validity and reliability of the data. The classical assumptions used are normality test, multicollinearity, and heteroscedasticity test. Model analysis uses multiple linear regression is used to analyze data with the help of the SPSS.23.0 program. The results showed that budget participation had a significant effect on managerial performance and organizational culture had a significant effect on managerial performance.
\end{abstract}

Keywords: Participation budget, organizational culture, managerial performance.

\section{Pendahuluan}

Pada era globalisasi saat ini, bangsa Indonesia dihadapkan pada kenyataan akan perubahan yang semakin cepat, dimana realitas akan berjalan dalam pola yang tidak teratur, dan apa yang akan terjadi di masa yang akan datang, sangat sulit bahkan tidak dapat diprediksi. Dari hal tersebut manajemen dituntut untuk mengelola perusahaan secara efisien agar perusahaan dapat bertahan dan berkembang dalam menghadapi persaingan yang ketat.Pihak manajemen dituntut untuk lebih berhati-hati dalam 
melakukan perencanaan, pengorganisasian, penyusunan, pengarahan, serta pengawasan atau pengendalian terhadap bawahan dalam rangka mencapai tujuan entitas.

Begitu juga pada manajemen perusahaan telah melakukan perbaikan secara terus menerus dalam mencapai target yang telah ditetapkan perusahaan. Dengan selisih antara target dan realisasi laba yang dialami perusahaan, terlihat bahwa terdapat gap dalam usaha pencapaian target laba dengan realisasi yang ada dalam perusahaan. penurunan laba ini mungkin disebabkan oleh kinerja manajerial perusahaan yang kurang efektif dan efisien. Misalnya: kurangnya kerjasama antara manajer, kreativitas karyawan yang menurun. Untuk itu diperlukan suatu kerjasama antar manajer yang kuat untuk meningkatkan kinerja perusahaan sehingga tujuan perusahaan dapat tercapai. Kinerja organisasi yang dihasilkan tersebut erat kaitannya dengan kinerja manajerial.hal ini dikarenakan semakin baiknya kinerja seorang manajer akan berpengaruh dengan semakin baiknya kinerja organisasi tersebut. Kinerja manajerial ini membantu perusahaan untuk mencapai sebuah kinerja organisasi yang baik dengan segalah arah dan tindakan yang dilakukan oleh manajer.

Perusahaan perlu memperhatikan budaya organisasi yang dapat mempengaruhi kinerja dan perilaku setiap pihak dalam organisasi. Budaya organisasi merupakan seperangkat asumsi atau sistem keyakinan, nilai-nilai dan norma yang dikembangkan dalam organisasi yang dijadikan pedoman tingkah laku bagi anggota-anggotanya untuk mengatasi masalah adaptasi eksternal dan integrasi internal. (Mangkunegara, 2005). Budaya organisasi merupakan sistem penyebaran kepercayaan dan nilai-nilai yang berkembang dalam suatu organisasi dan mengarahkan perilaku anggota-anggotanya. Budaya organisasi dapat menjadi instrumen keunggulan kompetitif yang utama, yaitu bila budaya organisasi mendukung strategi organisasi, dan bila budaya organisasi dapat menjawab atau mengatasi tantangan lingkungan dengan cepat dan tepat (Soedjono, 2005). Tujuan dari budaya organisasi ini yaitu agar seluruh individu dalam perusahaan mematuhi dan berpedoman pada sistem nilai keyakinan serta norma yang berlaku dalam perusahaan. Sehingga dengan memperkuat budaya yang sesuai dengan perusahaan, diharapkan kinerja manajerial perusahaan pun ikut meningkat.

Kesuksesan organisasi selain diukur dari karyawan dan keterkaitan budaya yang melekat padanya, juga dapat dilihat dari kinerja organisasi secara keseluruhan. Seorang manajer akan memengaruhi organisasi, baik buruknya organisasi berhubungan dengan kinerja manajerial (Budiman dkk., 2014). Semakin kuat budaya organisasi akan berdampak pula akan semakin bersemangatnya para pegawai untuk maju bersama dalam rangka membangun organisasi yang efektif dan efisien sesuai dengan visi, misi, dan tujuan yang hendak dicapai. Selain menjadi pemersatu pegawai, budaya organisasi juga sebagai peredam konflik dan motivator pegawai untuk melaksanakan tugas dengan baik, sehingga berprilaku positif terhadap perilaku dan kinerja pegawai (Wibowo, 2013). Penelitian terdahulu yang dilakukan oleh Rusman Soleman (2012), menyatakan bahwa interaksi penganggaran partisipatif dan budaya organisasi berpengaruh negatif terhadap kinerja manajerial. Naswa Rochani Rawdhyfa (2018), menyatakan bahwa Budaya organisasi memperkuat hubungan antara partisipasi anggaran dan kinerja manajerial. Artinya dengan budaya organisasi yang kuat dan mengarahkan orang-orang dalam 
organisasi dapat meningkatkan kinerja karyawan. Namun penelitian Eniza Wati (2013) menyatakan budaya organisasi yang berorientasi pada orang tidak dapat memperkuat hubungan Partisipasi Penyusasunan Anggaran terhadap Kinerja Pemerintah Daerah. Hal ini didukung dengan hasil penelitian Ghaliyah Nimassita Triseptya (2017) menyatakan bahwa budaya organisasi tidak berpengaruh terhadap kinerja manajerial.

Dalam penganggaran, proses penyusunan anggaran merupakan masalah yang penting bagi keberhasilan anggaran dan kinerja perusahaan (Alim, 2013). Dalam proses penyusunan anggaran, faktor-faktor yang perlu diperhatikan adalah partisipasi dalam penyusunan anggaran. Pada penganggaran bottom-up (partisipasif), manajer level bawah memiliki kewenangan untuk ikut dalam pengajuan anggaran, kecenderungan anggaran yang dihasilkan oleh manajer-manajer tersebut akan lebih bersifat objektif karena informasi-informasi disetiap bagaian dapat dimasukkan dalam proses penganggaran. Selain itu, partisipasi dalam penyusunan anggaran memungkinkan para manajer menyalurkan pengetahuan, kemampuan dan keahliannya untuk meningkatkan kinerja manajerial.

PT Perkebunan Nusantara VIII merupakan perkebunan milik negara yang bergerak disektor Agribisnis dan Agroindustri dengan kegiatan usaha meliputi budidaya, persiapan lahan, pembibitan, penanaman, pemeliharaan, pengelolaan dan penjualan komoditas perkebunan, serta optimalisasi pemanfaatan sumber daya perseroan dengan luas areal 113.958 ha. Berdasarkan analisis dan pembahasan manajemen, Tahun 2019 kinerja operasional perusahaan dalam kondisi di bawah standar pencapaian target Rencana Kerja Anggaran Perusahaan (RKAP) terutama produksi dan produktivitas dimana pada kurun 5 tahun terakhir (2015-2019) cenderung mengalami penurunan kecuali kelapa sawit. Kondisi SDM baik jumlah, komposisi umur, tingkat pendidikan maupun kompetensi belum ideal, sehingga hal tersebut berdampak pada kondisi keuangan perusahaan yang cenderung menurun dimana perusahaan terus merugi dengan pendapatan usaha yang semakin menurun pada kurun waktu 5 tahun (2015-2019). Dengan memperhatikan kondisi perusahaan tersebut, dalam 5 tahun ke depan diperlukan upaya untuk menyelamatkan, penyehatan dan pengembangan perusahaan dengan melakukan progam restrukturisasi di bidang SDM, Operasional, dan Keuangan..

Proses penyusunan anggaran yang melibatkan para bawahan dapat meningkatkan kinerja bawahan dalam mencapai target anggaran. Anggaran partisipatif dapat dilakukan untuk mencapai target anggaran dengan cara negosiasi antara atasan bawahan. Oleh karena itu, partisipasi penyusunan anggaran perlu melibatkan berbagai tingkat manajerial atau tingkatan pejabat strukutral dalam organisasi serta peranan pejabat strutural. Proses penyusunan anggaran tersebut memerlukan kerjasama yang baik antara atasan dan bawahan. Anggaran yang telah disusun secara partisipatif kemudian disahkan dengan para manajer dari setiap divisi dan pusat pertanggungjawaban dalam suatu organisasi. Manajemen puncak menciptakan berbagai divisi tanggungjawab atau dikenal dengan pusat pertanggungjawaban. Akuntansi pertanggungjawaban memainkan peran dalam mengukur kegiatan dan hasilnya termasuk dalam pelaksanaan anggaran yang telah disusun dengan pusat pertanggungjawaban lainnya. 
Berbeda dari penelitian yang dilakukan sebelumnya, penulis melakukan penelitian tentang Pengaruh Partisipasi Penyusunan Anggaran dan Budaya Organisasi terhadap Kinerja Manajerial pada PT Perkebunan Nusantara VIII (Studi Kasus Kebun Teh Pasir Malang PTPN VIII). Adapun Tujuan Penelitian dalam penelitian ini adalah untuk memperoleh bukti yang empiris mengenai pengaruh partisipasi anggaran terhadap kinerja manajerial pada BUMN PTPN VIII dan untuk memperoleh bukti empiris mengenai pengaruh budaya organisasi terhadap kinerja manajerial pada BUMN PTPN VIII

\section{Kerangka Teori \\ Partisipasi penyusunan anggaran terhadap kinerja manajerial}

Partisipasi anggaran melibatkan manajer baik dalam mengusulkan, menyusun, dan melaksanakan anggaran pada pusat pertanggungjawaban. Penganggaran partisipatif (participative budgeting) memberikan kesempatan bagi para manajer untuk ikut menyusun anggaran (Hansen dan Mowen, 2006). Dalam menyusun anggaran secara partisipasif diharapkan kinerja manajerial akan meningkat. Anggaran yang telah disusun memiliki peranan sebagai perencanaan dan sebagai kriteria kinerja, yaitu anggaran dipakai sebagai suatu sistem pengendalian untuk mengukur kinerja manajer. Untuk mencegah dampak fungsional atau disfungsionalnya, sikap dan perilaku anggota organisasi dalam penyusunan anggaran, perlu melibatkan manajemen pada level yang lebih rendah sehingga anggaran partisipatif dapat dinilai sebagai pendekatan manajerial yang dapat meningkatkan kinerja setiap anggota organisasi (Sardjito dan Muthaher, 2007).

Partisipasi penyusunan anggaran diharapkan meningkatkan kinerja manajerial, yakni, ketika tujuan telah direncanakan dan disetujui secara partisipatif, karyawan akan menginternalisasi tujuan tersebut dan mereka akan memiliki tanggung jawab secara personal untuk mencapainya melalui keterlibatan dalam proses anggaran (Milani, 1975). Menurut Brownell (1982) partisipasi umumnya dinilai sebagai suatu pendekatan manajerial yang dapat meningkatkan kinerja anggota organisasi. Brownell (1982) melakukan penelitian terhadap 48 manajer pusat biaya level menengah di San Fransicso yang mengukur hubungan antara partisipasi anggaran dengan kinerja manajerial dan menemukan hubungan positif dan signifikan. Brownell dan McInnes (1986) juga melakukan penelitian melalui 224 responden dari manajer tingkat menengah di tiga perusahaan manufaktur. Mereka menemukan bahwa partisipasi yang tinggi dalam penyusunan anggaran meningkatkan kinerja manajerial.

Hal ini didukung dengan adanya beberapa hasil penelitian terdahulu yaitu, penelitian yang dilakukan oleh Hapsari (2010), Fitri Ella Fauziah (2013), Mutiara Sri Rezeki (2017), Ghaliyah Nimassita Triseptya (2017), dan Hetty Mariana Tanjung (2017) menyatakan bahwa partisipasi anggaran berpengaruh secara signifikan terhadap kinerja manajerial, artinya dengan tingkat partisipasi yang tinggi maka kinerja manajerial pun meningkat.

Berdasarkan uraian diatas maka seperti yang telah dikemukakan sebelumnya, penelitian ini dimaksudkan untuk menguji kembali hubungan partisipasi dalam 
penyusunan anggaran terhadap kinerja manajerial dengan rumusan hipotesis sebagai berikut.

H1 : Partisipasi dalam penyusunan anggaran berpengaruh positif dan signifikan terhadap kinerja manajerial.

\section{Pengaruh Budaya Organisasi terhadap Kinerja Manajerial}

Budaya organisasi merupakan seperangkat asumsi dasar dan keyakinan yang dianut oleh anggota anggota organisasi yang kemudian digunakan untuk mengatasi masalah internal maupun eksternal organisasi. Budaya organisasi yang kuat adalah budaya yang hampir semua manajer menganut bersama seperangkat nilai dan metode menjalankan bisnis yang relatif konsisten (Pabundu, 2006).

Pernyataan tersebut didukung Pendapat Holmes dan Marsden (1996) dalam Sardjito (2007), Budaya Organisasi mempunyai pengaruh terhadap perilaku, cara kerja dan motivasi para manajer dan bawahannya untuk mencapai kinerja organisasi. Hasil Penelitian Subramaniam dan Ashkanasy (2001) menyimpulkan bahwa Budaya Organisasi mempunyai pengaruh yang signifikan dalam memoderasi hubungan Penyusunan Anggaran Partisipatif dan Kinerja Manajerial. Hal ini diperkuat oleh hasil penelitan oleh Alam dan Mia (2006) yang menemukan bahwa Budaya Organisasi mempengaruhi sikap para manajer untuk berpartisipasi dalam Penyusunan Anggaran Partisipatif, dengan semakin tinggi tingkat partisipasi mereka dalam penyusunan anggaran maka semakin tinggi kinerja mereka.

Penelitian yang dilakukan oleh Rusman Soleman (2012), menyatakan bahwa interaksi penganggaran partisipatif dan budaya organisasi berpengaruh negatif terhadap kinerja manajerial. Naswa Rochani Rawdhyfa (2018), menyatakan bahwa Budaya organisasi memperkuat hubungan antara partisipasi anggaran dan kinerja manajerial. Artinya dengan budaya organisasi yang kuat dan mengarahkan orang-orang dalam organisasi dapat meningkatkan kinerja karyawan.

Berdasarkan uraian di atas, dapat ditarik hipotesis sebagai berikut:

$\mathrm{H} 2$ : Budaya organisasi berpengaruh positif dan signifikan terhadap kinerja manajerial.

\section{Rerangka Konseptual}

Berikut adalah rerangka konseptual mengembangkan hipotesis penelitian:

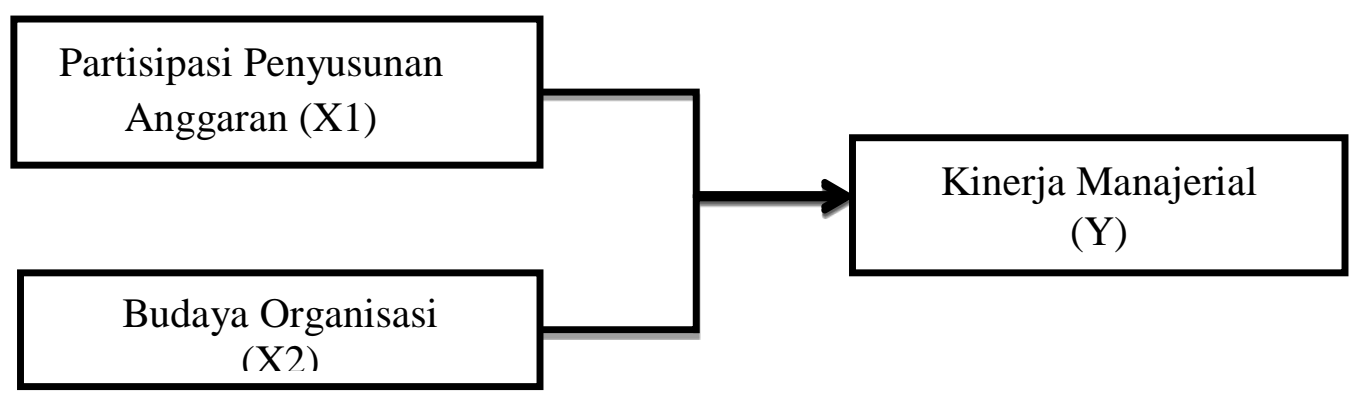

Gambar 1. Rerangka Konseptual 


\section{Metode Penelitian}

\section{Teknik Pengumpulan Data}

Banyak teknik pengumpulan data dalam kegiatan penelitian, akan tetapi di dalam penelitian ini hanya akan digunakan tiga teknik pengumpulan data yang disesuaikan dengan jenis-jenis data yang dikumpulkan dalam rangka mencari jawaban terhadap masalah penelitian. Teknik pengumpulan data melalui :

1. Teknik kuesioner adalah cara pengumpulan data yang dilakukan peneliti terhadap responden di PT Perkebunan Nusantara VIII, dengan cara menyusun daftar pertanyaan (kuesioner), lalu responden diminta untuk menjawab pilihan yang diperlukan, memilih jawaban yang paling tepat menurut dokumen para pejabat atau staf yang membidangi, setiap pertanyaan yang diajukan secara tertulis kepada responden.

2. Teknik Observasi adalah peneliti mengadakan pengamatan langsung kepada organisasi yang dijadikan objek untuk mendukung data yang diperlukan dalam hasil kuesioner.

3. Studi Pustaka adalah pengumpulan data melalui dokumen-dokumen, laporan-laporan baik bulanan dan tahunan juga referensi lain seperti peraturan-peraturan yang berlaku.

\section{Definisi Operasional dan Pengukuran Variabel}

Variabel independen dalam penelitian ini ada dua, yaitu partisipasi penyusunan anggaran dan budaya organisasi. Partisipasi anggaran sebagai variabel independen dalam penelitian ini adalah kontribusi manajer kebun teh. Variabel ini diukur dengan menggunakan indikator-indikator yang dikembangkan oleh Sinaga (2009), yang terdiri dari 11 (sebelas) pertanyaan dengan 5 skala ordinal. Variabel independen kedua yaitu budaya organisasi. budaya organisasi dikembangkan oleh Sinaga (2009), yang terdiri 19 (sembilan belas) pertanyaan dengan 5 skala ordinal.

Variabel dependen dalam penelitian ini yaitu kinerja manajerial. Variabel ini diukur dengan menggunakan indikator-indikator yang dikembangkan oleh Sinaga (2009), yang terdiri dari 9 (sembilan) pertanyaan dengan 5 skala ordinal.

\section{Metode Pengolahan Data}

Untuk mempermudah pengolahan data, penulis menggunakan software Microsoft Office Excel 2010 dan SPSS 23. Pengolahan dan analisis data setiap variabel yang digunakan dalam penelitian, baik variabel-variabel independen maupun variabel dependen, akan menggunakan Microsoft Office Excel 2010 untuk mengetahui perkembangan data kuantitatif setiap variabel dari tahun ke tahun. 


\section{Statistik Deskriptif}

Gambaran mengenai variabel-variabel penelitian disajikan dalam tabel descriptive statistics. Pada tabel berikut.

Tabel 6. Analisis Statistik Deskriptif

\begin{tabular}{|l|c|c|c|c|c|}
\hline & N & Minimum & Maximum & Mean & $\begin{array}{c}\text { Std. } \\
\text { Deviation }\end{array}$ \\
\hline Partisipasi Penyusunan Anggaran & 63 & 11.00 & 20.00 & 14.8500 & 2.46209 \\
\hline Budaya Organisasi & 63 & 9.00 & 22.00 & 16.6000 & 2.41605 \\
\hline Kinerja Manajerial & 63 & 12.00 & 24.00 & 16.7667 & 2.25017 \\
\hline
\end{tabular}

Sumber: Hasil Pengolahan SPSS 23 (2020)

\section{Hasil Penelitian dan Pembahasan}

\section{Gambaran Umum Objek Penelitian}

Penelitian ini bertujuan untuk melihat apakah ada pengaruh antara partisipasi penyusunan anggaran dan budaya organisasi terhadap kinerja manajerial sebagai variabel dependen dengan objek penelitian terhadap BUMN PTPN VIII. Jumlah populasi penelitian ini adalah 23 kebun teh PTPN VIII di Jawa Barat. Adapun daftar kebun teh yang menjadi sampel penelitian adalah sebagai berikut:

Tabel 1. Daftar Kebuh Teh PTPN VIII

\begin{tabular}{|c|l|l|c|}
\hline NO & \multicolumn{1}{|c|}{ Kabupaten } & \multicolumn{1}{|c|}{ Kebun } & Budidaya \\
\hline 1 & Bogor & Gunung Mas & Teh \\
\hline 2 & Bogor & Cianten & Teh \\
\hline 3 & Sukabumi & Parakan Salak & Teh \\
\hline 4 & Sukabumi & Goal Para & Teh \\
\hline 5 & Cianjur & Gedeh & Teh \\
\hline 6 & Cianjur & Panyairan & Teh \\
\hline 7 & Cianjur & Pasirnangka & Teh \\
\hline 8 & Bandung & Pasirmalang & Teh \\
\hline 9 & Bandung & Sinumbra & Teh \\
\hline 10 & Bandung & Rancabali & Teh \\
\hline 11 & Bandung & Rancabolang & Teh \\
\hline 12 & Bandung & Montaya & Teh \\
\hline 13 & Bandung & Kertamanah & Teh \\
\hline 14 & Bandung & Malabar & Teh \\
\hline 15 & Bandung & Purbasari & Teh \\
\hline 16 & Bandung & Sedep & Teh \\
\hline 17 & Bandung & Talunsantosa & Teh \\
\hline 18 & Bandung & Pangheotan & Teh \\
\hline 19 & Subang & Ciater & Teh dan Sawit \\
\hline 20 & Subang & Tambaksari & Teh \\
\hline 21 & Garut & Papandayan & Teh \\
\hline 22 & Garut & Cisaruni & Teh \\
\hline 23 & Garut & Dayeuh Manggung & \\
\hline & & & \\
\hline
\end{tabular}


Populasi penelitian yang menjadi responden adalah manajer kebun, asisten kepala, asisten, dan mandor besar PTPN VIII (Persero) yang terlibat dalam proses partisipasi (mengusulkan dan atau melaksanakan) anggaran. Teknik penarikan sampel dilakukan dengan menggunakan metode pemilihan sampel bertujuan (purposive sampling) dengan kriteria yang ditetapkan. Berdasarkan kriteria tersebut, jumlah sampel yang memenuhi syarat sebanyak 63 orang dari 23 kebun teh PTPN VIII di Jawa Barat. Adapun karakteristik populasi yang menjadi responden, yaitu:

\section{Karakteristik Responden Berdasarkan Jenis Kelamin}

Jenis kelamin responden digunakan untuk mengetahui keterlibatan gender dalam proses penganggaran di PTPN VIII. Sampel penelitian untuk 63 orang responden berdasarkan jenis kelamin dapat dilihat pada tabel berikut:

Tabel 2. Profil Responden Berdasarkan Jenis Kelamin

\begin{tabular}{|l|c|c|}
\hline Jenis Kelamin & Jumlah & Persentase \\
\hline Laki-Laki & 51 & $80,95 \%$ \\
\hline Perempuan & 12 & $19,05 \%$ \\
\hline Total & 63 & $100 \%$ \\
\hline
\end{tabular}

Dilihat pada Tabel 2, sebagian besar responden yang berpartisipasi dalam penelitian ini adalah berjenis kelamin laki-laki yaitu sebanyak 51 orang responden $(80,95 \%)$, sedangkan responden yang berjenis kelamin perempuan sebanyak 12 orang $(19,05 \%)$.

\section{Karakteristik Responden Berdasarkan Umur Responden}

Umur responden diharapkan dapat menggambarkan tingkat pengalaman atau posisi pejabat struktural. Sampel penelitian untuk 63 orang responden berdasarkan usia dapat ditunjukkan pada tabel :

Tabel 3. Profil Responden Berdasarkan Umur

\begin{tabular}{|l|c|c|}
\hline \multicolumn{1}{|c|}{ Umur } & Jumlah & Persentase \\
\hline $15-25$ tahun & 3 & $5 \%$ \\
\hline $26-35$ tahun & 7 & $11 \%$ \\
\hline $36-45$ tahun & 17 & $26,98 \%$ \\
\hline$>45$ tahun & 36 & $57 \%$ \\
\hline Total & 63 & $100 \%$ \\
\hline
\end{tabular}

Berdasarkan Tabel 3, sebagian besar responden berumur lebih dari 45 tahun yaitu sebanyak 57\%, sedangkan yang berumur 15-25 tahun sebanyak 5\%, umur 26-35 tahun sebanyak $11 \%$, dan umur 36-45 tahun sebanyak $26,98 \%$

\section{Karakteristik Responden Berdasarkan Tingkat Pendidikan}

Tingkat pendidikan responden diharapkan dapat digunakan sebagai indikator untuk mengetahui tingkat kapasitas individu yang berpartisipasi dalam proses penganggaran. Sampel penelitian sebesar 63 responden dilihat dari tingkat pendidikan dapat ditunjukkan pada tabel 4: 
Tabel 4. Profil Responden Berdasarkan Tingkat Pendidikan

\begin{tabular}{|l|c|c|}
\hline Pendidikan & Jumlah & Persentase \\
\hline SMA & 24 & $38,10 \%$ \\
\hline Diploma & 13 & $20,63 \%$ \\
\hline S1 & 20 & $31,75 \%$ \\
\hline S2 & 6 & $9,52 \%$ \\
\hline Total & 63 & $100 \%$ \\
\hline
\end{tabular}

Sebagian besar responden berpendidikan SMA sebanyak 24 orang $(38,10 \%)$, sedangkan diploma (D3) sebanyak 13 orang (20,63\%), Sarjana (S1) sebanyak 20 orang $(31,75 \%)$, dan pascasarjana (S2) sebanyak 6 orang $(9,52 \%)$. Berdasarkan tabel di atas, tingkat pendidikan responden dianggap cukup baik.

\section{Karakteristik Responden Berdasarkan Eselon}

Sampel penelitian untuk 63 orang responden berdasarkan jabatan dapat ditunjukkan pada tabel 5:

Tabel 5. Profil Responden Berdasarkan Jabatan

\begin{tabular}{|l|c|c|}
\hline \multicolumn{1}{|c|}{ Jabatan Kerja } & Jumlah & Persentase \\
\hline Manajer Kebun & 12 & $19,05 \%$ \\
\hline Asisten Kepala & 11 & $17,46 \%$ \\
\hline Asisten & 17 & $26,98 \%$ \\
\hline Mandor Besar & 23 & $36,51 \%$ \\
\hline Total & 63 & $100 \%$ \\
\hline
\end{tabular}

Jabatan responden yang berpartisipasi dalam penelitian ini, adalah manajer kebun sebanyak 12 orang $(19,05 \%)$, asisten kepala sebanyak 11 orang $(17,46 \%)$, asisten sebanyak 17 orang $(26,98 \%)$, dan mandor besar sebanyak 23 orang $(36,51 \%)$. Dari semua responden yang paling banyak mengisi kuesioner adalah mandor besar.

\section{Hasil Uji Validitas data}

Jika $r$ hitung $\geq r$ tabel, maka item-item pernyataan dinyatakan valid.Nilai $r$ tabel dapat dilihat pada tabel $\mathrm{r}$ dengan persamaan $\mathrm{N}-2=63-2=61=0,254$. Diketahui bahwa nilai $r$ hitung seluruh item pernyataan $>r$ tabel $(0,254)$. Dengan demikian dapat diartikan bahwa seluruh item pernyataan dinyatakan valid.

Tabel 7. Hasil Uji Validitas Data

\begin{tabular}{|l|c|c|c|c|}
\hline \multicolumn{1}{|c|}{ Variabel } & Pernyataan & r hitung & r tabel & Keputusan \\
\hline Partisipasi Penyusunan Anggaran & PA1 & 0,688 & 0,254 & Valid \\
\cline { 2 - 5 } & PA2 & 0,528 & 0,254 & Valid \\
\cline { 2 - 5 } & PA3 & 0,682 & 0,254 & Valid \\
\cline { 2 - 5 } & PA4 & 0,609 & 0,254 & Valid \\
\cline { 2 - 5 } & PA5 & 0,699 & 0,254 & Valid \\
\cline { 2 - 5 } & PA6 & 0,645 & 0,254 & Valid \\
\cline { 2 - 5 } & PA7 & 0,429 & 0,254 & Valid \\
\hline
\end{tabular}




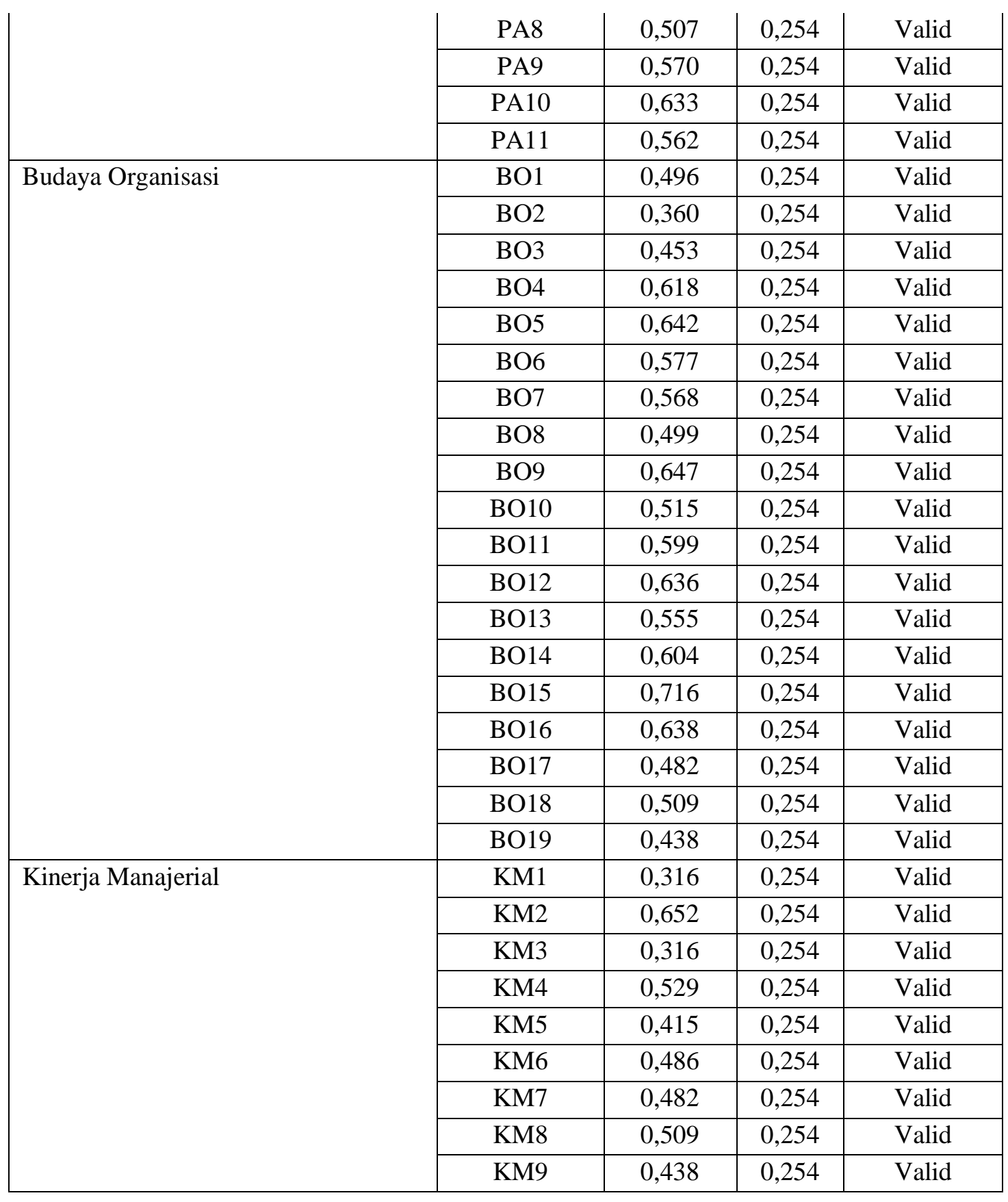

\section{Hasil Uji Reliabilitas}

Instrumen dalam variabel dikatakan reliabel jika memiliki Cronbach Alpha lebih dari 0,6. Hasil uji reliabilitas atas instrumen penelitian dapat ditunjukkan dalamsebagai berikut: 
Tabel 8. Hasil Uji Reliabilitas

\begin{tabular}{|l|l|l|l|}
\hline \multirow{2}{*}{ Variabel } & Cronbach's & Nilai & \multirow{2}{*}{ Kesimpulan } \\
\cline { 2 - 3 } & \multicolumn{1}{|c|}{ Alpha } & Kritis & \\
\hline $\begin{array}{l}\text { Partisipasi } \\
\text { Penyusunan } \\
\text { Anggaran }\end{array}$ & 0,854 & 0,6 & Reliabel \\
\hline $\begin{array}{l}\text { Budaya } \\
\text { Organisasi }\end{array}$ & 0,782 & 0,6 & Reliabel \\
\hline $\begin{array}{l}\text { Kinerja } \\
\text { Manajerial }\end{array}$ & 0,756 & 0,6 & Reliabel \\
\hline
\end{tabular}

Sumber: Hasil Pengolahan SPSS 23 (2020)

Jika nilai reliabilitas kurang dari 0,6 maka nilainya kurang baik. Artinya adalah bahwa alat ukur yang digunakan tidak reliable.Nilai reliabilitas dalam uji ini adalah pada kolom Reliabilitiy Statistics (Cronbach's Alpha). Diketahui bahwa seluruh nilai Cronbach's Alpha $>0,6$. Dengan demikian dapat diartikan bahwa alat ukur yang digunakan reliabel atau dapat dipercaya.

Hasil Uji Normalitas

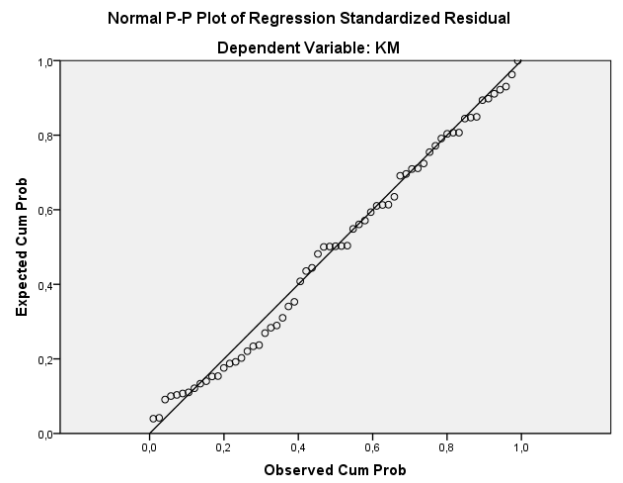

Gambar 2 Hasil Uji Normalitas

Berdasarkan gambar Normal PP Plot diatas terlihat bahwa titik- titik menyebar disekitar dan mengikuti garis diagonal.Dapat diartikan bahwa model regresi memenuhi asumsi normalitas. 
Tabel 9. One Sample Kolmogorov Smirnov Test

\begin{tabular}{|ll|l|}
\hline & & $\begin{array}{l}\text { Unstandardi } \\
\text { zed Residual }\end{array}$ \\
\hline $\mathrm{N}$ & Mean & 63 \\
Normal Parameters & 0 \\
& Std. Deviation & 1.38833822 \\
& Absolute & 0.07 \\
Most Extreme Differences & Positive & 0.07 \\
& Negative & -0.055 \\
Kolmogorov-Smirnov Z & & 0.543 \\
Asymp. Sig. (2-tailed) & & 0.93 \\
\hline
\end{tabular}

Sumber: Hasil Pengolahan SPSS 23 (2020)

Berdasarkan Gambar Normal PP Plot diatas terlihat bahwa titik- titik menyebar disekitar dan mengikuti garis diagonal. Kemudian berdasarkan uji Komogorov Smirnov diperoleh nilai signifikansi sebesar 0,930 > 0,05. Dapat diartikan bahwa model regresi memenuhi asumsi normalitas

\section{Hasil Uji Multikolinearitas}

Tabel 10. Hasil Uji Multikolinearitas

\begin{tabular}{|ll|c|c|}
\hline \multirow{2}{*}{ Model } & \multicolumn{2}{|c|}{ Collinearity Statistics } \\
\cline { 2 - 3 } & (Constant) & Tolerance & VIF \\
\hline \multicolumn{2}{|c|}{ Partisipasi Penyusunan Anggaran } & 0.729 & 1.373 \\
$1 \quad$ Budaya organisasi & 0.705 & 1.418 \\
\hline
\end{tabular}

Sumber: Hasil Pengolahan SPSS 23 (2020)

Dari tabel diatas, diperoleh nilai VIF untuk seluruh variabel bebas $<10$ dan tolerance $>0,10$. Hal ini dapat disimpulkan bahwa model regresi tersebut bebas dari multikolinearitas.

\section{Hasil Uji Heteroskedastisitas}

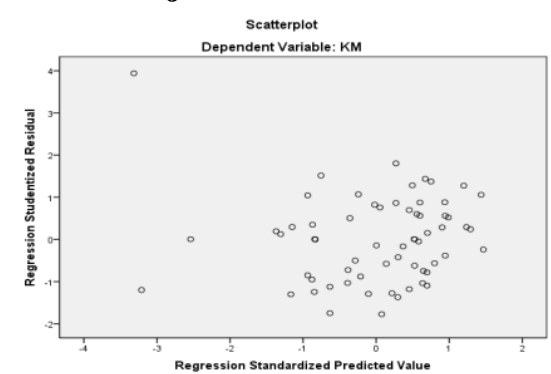

Gambar 3 Heteroskedastisitas

Dari gambar Scatterplot terlihat bahwa titik-titik tidak membentuk pola tertentu dan menyebar secara acak diatas dan dibawah angka 0 pada sumbu Y. Dapat diartikan tidak terdapat heterokedastisitas dalam model regresi penelitian ini. 


\section{Hasil Uji Autokorelasi}

Tabel 11. Hasil Uji Autokorelasi

\begin{tabular}{|l|c|l|l|l|l|}
\hline Model & $\mathrm{R}$ & $\begin{array}{l}\mathrm{R} \\
\text { Square }\end{array}$ & $\begin{array}{l}\text { Adjusted R } \\
\text { Square }\end{array}$ & $\begin{array}{l}\text { Std.Error of the } \\
\text { Estimate }\end{array}$ & $\begin{array}{l}\text { Durbin } \\
\text { Watson }\end{array}$ \\
\hline 1 & $0,679 \mathrm{a}$ & 0,461 & 0,443 & 3,231 & 1,761 \\
\hline
\end{tabular}

Sumber: Hasil Pengolahan SPSS 23 (2020)

Dari tabel diatas diperoleh nilai Durbin Watson terletak antara -2 dan $+2=-2<$ $1,761<+2$. Hal ini dapat disimpulkan bahwa tidak terdapat autokorelasi dalam model regresi.

\section{Hasil Analisis Regresi Linier Berganda}

Tabel 12. Hasil Analisis Regresi linier Berganda

\begin{tabular}{|c|l|c|l|l|c|l|}
\hline \multicolumn{2}{|c|}{ Coefficients $^{\mathbf{a}}$} \\
\hline \multirow{2}{*}{ Model } & $\begin{array}{c}\text { Unstandardized } \\
\text { Coefficients }\end{array}$ & B & Std. Error & $\begin{array}{c}\text { Standardized } \\
\text { Coefficients }\end{array}$ & $\mathrm{t}$ & Seta \\
\cline { 2 - 7 } & (Constant) & 20,456 & 3,106 & & 6,585 & 0,000 \\
\hline 1 & $\begin{array}{l}\text { Partisipasi } \\
\text { Penyusunan } \\
\text { Anggaran }\end{array}$ & 0,303 & 0,073 & 0.466 & 4,153 & 0,000 \\
\hline 2 & $\begin{array}{l}\text { Budaya } \\
\text { Organisasi }\end{array}$ & 0,107 & 0,040 & 0.303 & 2,697 & 0,009 \\
\hline
\end{tabular}

Dari data analisis regresi linier berganda seperti yang ditunjukkan pada Tabel di atas, dapat dirumuskan suatu persamaan regresi linier berganda sebagai berikut: $\mathrm{Y}=20,456+0,303 \mathrm{X}_{1}+0,107 \mathrm{X}_{2}+\mathrm{e}$

Arti angka-angka dalam persamaan regresi diatas:

1. Nilai konstanta (a) sebesar 20,456. Artinya adalah apabila variabel independen diasumsikan nol (0), maka kinerja manajerial sebesar 20,456.

2. Nilai koefisien regresi variabel partisipasi penyusunan anggaran sebesar 0,303. Artinya adalah bahwa setiap peningkatan partisipasi penyusunan anggaran sebesar 1 satuan maka akan meningkatkan kinerja manajerial sebesar 0,303 dengan asumsi variabel lain tetap.

3. Nilai koefisien regresi variabel budaya organisasi sebesar 0,107. Artinya adalah bahwa setiap peningkatan budaya organisasi sebesar 1 satuan maka akan meningkatkan kinerja manajerial sebesar 0,107 dengan asumsi variabel lain tetap.

4. Standar error $(e)$ merupakan variabel acak dan mempunyai distribusi probabilitas yang mewakili semua faktor yang mempunyai pengaruh terhadap $\mathrm{Y}$ tetapi tidak dimasukan dalam persamaan. 


\section{Hasil Uji Koefisien Determinasi $\left(\mathbf{R}^{2}\right)$}

Tabel 13. Hasil Uji Koefisien Determinasi Model Summary

\begin{tabular}{|l|c|c|c|l|l|}
\hline $\begin{array}{l}\text { Mo } \\
\text { del }\end{array}$ & $\mathrm{R}$ & $\begin{array}{l}\mathrm{R} \\
\text { Square }\end{array}$ & $\begin{array}{l}\text { Adjusted } \mathrm{R} \\
\text { Square }\end{array}$ & $\begin{array}{l}\text { Std.Error of the } \\
\text { Estimate }\end{array}$ & $\begin{array}{l}\text { Durbin } \\
\text { Watson }\end{array}$ \\
\hline 1 & $0,679 \mathrm{a}$ & 0,461 & 0,443 & 3,231 & 1,761 \\
\hline
\end{tabular}

Sumber: Hasil Pengolahan SPSS 23 (2020)

Diketahui nilai Adjusted R Square sebesar 0,443. Artinya adalah bahwa sumbangan pengaruh variabel independen terhadap variabel dependen adalah sebesar 44,3\%. Sedangkan sisanya $55,7 \%$ \% dipengaruhi oleh variabel lain yang tidak dimasukkan dalam model regresi ini.

\section{Hasil Uji Koefisien Regresi Secara Parsial ( Uji t)}

Berdasarkan data dari tabel diketahui nilai ttabelpada taraf signifikan 5\% dengan bersamaan sebagai berikut :

\begin{tabular}{|c|l|c|c|c|c|l|}
\hline \multicolumn{7}{|c|}{$\begin{array}{c}\text { Tabel 14. Hasil Uji T } \\
\text { Coefficients }\end{array}$} \\
\hline \multirow{2}{*}{} & $\begin{array}{l}\text { Unstandardized } \\
\text { Coefficients }\end{array}$ & & $\begin{array}{l}\text { Standardized } \\
\text { Coefficients }\end{array}$ & t & Sig. \\
\cline { 2 - 7 } & B & Std. Error & Beta & & \\
\hline & (Constant) & 20,456 & 3,106 & & 6,585 & 0,000 \\
\hline & $\begin{array}{l}\text { Partisipasi } \\
\text { Penyusunan } \\
\text { Anggaran }\end{array}$ & 0.303 & 0,073 & 0.466 & 4,153 & 0,000 \\
\hline 2 & Budaya Organisasi & 0.107 & 0,040 & 0.303 & 2,697 & 0,009 \\
\hline
\end{tabular}

Sumber: Hasil Pengolahan SPSS 23 (2020)

Diketahui nilai $\mathrm{t}$ tabel pada taraf signifikansi $5 \%$ (2-tailed) dengan Persamaan berikut:

$\mathrm{t}$ tabel $=\mathrm{n}-\mathrm{k}-1:$ alpha/ 2

$=63-3-1: 0,05 / 2$

$=59: 0,025$

$=2,003$

keterangan:

$\mathrm{n}$ : jumlah sampel

$\mathrm{k}$ : jumlah variabel bebas

$1:$ konstan

1. Partisipasi Anggaran. Diketahui t hitung 4,153>t tabel 1,998 dan Sig. 0,000<0,05. Artinya variabel partisipasi penyusunan anggaran berpengaruh signifikan terhadap kinerja manajerial. 
2. Budaya organisasi. Diketahui t hitung 2,697> t tabel 1,998 dan Sig. 0,009<0,05. Artinya variabel budaya organisasi berpengaruh signifikan terhadap kinerja manajerial.

\section{Pembahasan}

\section{Pengaruh partisipasi anggaran terhadap kinerja manajerial}

Hasil uji t statistik, dapat dilihat bahwa sig dari variabel partisipasi bernilai 0,001 dan dengan nilai t 4,153. Hal ini menyatakan bahwa H1 diterima, dimana variabel partisipasi anggaran berpengaruh secara signikan terhadap kinerja manajerial, dikarenakan nilai sig partisipasi anggaran 0,000 lebih kecil atau kurang dari nilai probabilitas $0,05(0,001<0,05)$. Partisipasi anggaran berpengaruh siginifikan karena dengan adanya anggaran secara partisipasi diharapkan kinerja manajer akan meningkat, dimana ketika suatu tujuan dirancang dan secara partisipasi disetujui, maka karyawan akan menginternalisasikan tujuan yang ditetapkan dan akan memiliki rasa tanggung jawab dalam penyusunan anggaran.

Partisipasi penyusunan anggaran ini merupakan keterlibatan seluruh manajer kebun, asisten kepala, asisten, mandor besar, dan mandor di 23 kebun teh PTPN VIII yang terlibat dalam proses partisipasi (mengusulkan dan atau melaksanakan) anggaran untuk melakukan kegiatan dalam pencapaian sasaran yang telah ditetapkan dalam anggaran. Dengan adanya keterlibatan tersebut akan mendorong para manajer untuk bertanggungjawab terhadap masing - masing tugas yang mereka miliki sehingga dapat meningkatkan kinerjanya agar mereka mencapai sasaran/target yang telah ditetapkan dalam anggaran. Hal ini mengindikasikan pengaruh signifikan terhadap kinerja manajerial. Kinerja manajer merupakan salah satu faktor yang dapat meningkatkan efektivitas organisasi. Partisipasi bawahan dalam penyusunan anggaran dan peran anggaran sebagai pengukur kinerja memiliki kaitan yang cukup kuat. Anggaran yang telah ditetapkan berfungsi sebagai perencanaan dan sebagai kriteria kinerja, yaitu anggaran dipakai sebagai suatu sistem pengendalian untuk mengukur kinerja manajerial. Proses penyusunan anggaran yang melibatkan para bawahan dapat meningkatkan kinerja bawahan dalam mencapai target anggaran. Anggaran partisipatif dapat dilakukan untuk mencapai target anggaran dengan cara negosiasi antara atasan bawahan.

Hal ini didukung dengan adanya beberapa hasil penelitian terdahulu yaitu, penelitian yang dilakukan oleh Hapsari (2010), Fitri Ella Fauziah (2013), Mutiara Sri Rezeki (2017), Ghaliyah Nimassita Triseptya (2017), dan Hetty Mariana Tanjung (2017) menyatakan bahwa partisipasi anggaran berpengaruh secara signifikan terhadap kinerja manajerial, artinya dengan tingkat partisipasi yang tinggi maka kinerja manajerial pun meningkat. Dengan demikian semakin tinggi partisipasi seorang manajer, kepala bagian, serta bawahan maka semakin tinggi pula tingkat kinerjanya.

\section{Pengaruh budaya organisasi terhadap kinerja manajerial}

Pada variabel budaya organisasi dapat dilihat bahwa nilai sig sebesar 0.009 dan nilai t 2,697. Hal ini menyatakan, bahwa variabel budaya organisasi memiliki nilai sig lebih kecil dari probabilitas $0,05(0,009<0,05)$ yang berarti $\mathrm{H} 2$ diterima dimana budaya 
organisasi berpengaruh secara signifikan terhadap kinerja manajerial. Artinya budaya organiasi yang kuat secara langsung berkaitan dengan kinerja manajerial yang optimal dengan mengutamakan kualitas dan kuantitas di kebun teh PTPN VIII. Karena seseorang yang memiliki budaya yang kuat akan cenderung menyukai pekerjaan ditekuninya, berupaya terlibat dengan organisasi dan memiliki loyalitas yang tinggi. Sehingga budaya organisasi dapat tumbuh dan berkembang karena manajer pusat tanggung jawab memiliki ikatan emosional terhadap perusahaan yang meliputi dukungan moral dan menerima nilai yang ada serta tekad dari dalam dirinya untuk mengabdi kepada perusahaan, budaya organisasi yang kuat dalam diri manajer pusat tanggung jawaban akan menyebabkan partisipasi mereka dalam penyusunan anggaran semakin tinggi sehingga akhirnya meningkat kinerja manajerial.

Pernyataan tersebut didukung penelitian yang dilakukan oleh Rusman Soleman (2012), menyatakan bahwa interaksi penganggaran partisipatif dan budaya organisasi berpengaruh negatif terhadap kinerja manajerial. Naswa Rochani Rawdhyfa (2018), menyatakan bahwa Budaya organisasi memperkuat hubungan antara partisipasi anggaran dan kinerja manajerial. Artinya dengan budaya organisasi yang kuat dan mengarahkan orang-orang dalam organisasi dapat meningkatkan kinerja karyawan.

\section{Simpulan dan Saran}

Berdasarkan hasil penelitian dan pembahasan mengenai pengaruh partisipasi anggaran, dan budaya organisasi terhadap kinerja manajerial dapat disimpulkan bahwa Partisipasi anggaran berpengaruh signifikan terhadap kinerja manajerial pada BUMN PTPN VIII dan Budaya organisasi berpengaruh signifikan terhadap kinerja manajerial pada BUMN PTPN VIII.

Untuk penelitian selanjutnya disarankan agar dapat memahami maksud penelitian tersebut, memanfaatkan waktu sebaik - baiknya untuk penyebaran dan pengumpulan kuesioner atau memperluaskan variabel. Jika data diperoleh dapat diperbanyak lagi, maka akan dapat meningkat kualitas yang bagus pada hasil penelitian. Penelitian ini diharapkan dapat dijadikan salah satu referensi untuk penelitian lebih lanjut terutama bagi penelitian yang melakukan penelitian yang berkaitan dengan partisipasi anggaran dan kinerja manajerial yang lebih sempurna dan komperehensif. Penelitian selanjutnya juga dapat menambahkan variable gaya kepimpinan, seleficacy baik serta menambahkan sebagai variable independen intervening.

\section{Daftar Pustaka}

Adrindrani, A.K. 2006. Akuntansi Manajemen. Penerbit Jogjakarta. Graha Ilmu.

Alim, M.N. 2013. "Pengaruh Ketidakpastian Stratejik dan Revisi Anggaran Terhadap Efektifitas Partisipasi Penyusunan Anggaran: Pendekatan Kontijensi". Proceeding Simposium Nasional Akuntansi V, Semarang. Pp. 626- 634. 
Fauziah, F.E. dan Hidayah, N. 2013. Pengaruh Partisipasi Anggaran Terhadap Kinerja Manajerial Dengan Budaya organisasi Sebagai Variabel Moderating. JurnalDinamika Ekonomi dan Bisnis.Vol.7 No. 1 Maret 2013.

Ghozali, I. 2009. Aplikasi Analisis Multivariate Dengan Program SPSS. Edisi Keempat, Semarang: Universitas Diponegoro.

Govindarajan dan Anthony. 2011.Sistem Pengendalian Manajemen, Jilid I dan II,. Jakarta, Salemba Empat.

Hansen dan Mowen. 2006. Akuntansi Manajemen buku 1.Edisi 7. Jakarta. Salemba Empat.

Hapsari. N. 2010. Pengaruh Partisipasi Anggaran terhadap Kinerja Manajerial dengan Budaya organisasidan Locus Of Control sebagai variabel Moderating Jurnal Ekonomi dan bisnis Indonesia, Vol. 15 No.1,2010 hal 97-14.

Mardiasmo. 2006. Akuntansi Sektor Publik, Edisi II, Yogyakarta, Penerbit Andi.

Milani, K.W. 1975. "The Relationship of Participation in Budget-Setting to Industrial Supervisor Performance and Attitudes: a Field Study", The Accounting Review, 50(2), pp. 274-284

Muthaher, O. dan Sardjito, B. 2007. Pengaruh Partisipasi Penyusunan Anggaran terhadap Kinerja Aparat Pemerintah Daerah: Budaya Organisasi dan Budaya organisasi sebagai Variabel ModeratingSimposium Nasional Akuntansi X, Unhas Makassar.

Nor, W. 2007. Desentralisasi dan Gaya Kepemimpinan sebagai Variabel Moderating dalam Hubungan antara Partisipasi Penyusunan Anggaran dan Kinerja Manajerial. Makalah disampaikan pada Simposium Nasional Akuntansi X.

Osborne, David \& Peter Plastrik. (2009). Memangkas Birokrasi: Lima Strategi Menuju Pemerintahan Wirausaha (Terjemahan Ramelan Abdul Rosyid), Jakarta: PPM.

Octavia, D. 2009. Pengaruh Partisipasi Anggaran, Gaya Kepemimpinan, dan Komitmen Organisasi, Terhadap Kinerja Manajerial Pada PT pos Indonesia (Perseron) Medan Skripsi Akuntansi Universitas Sumatera Utara.

Panagaran, R. 2008. "Pengaruh Partisipasi dalam penyusunan Anggaran Organisasi terhadap hubungan antara Partisipasi Anggaran dan Kinerja Manajerial pada PDAM tirtana diprovinsi sumatera utara" Tesis magister Akuntansi, Fakultas Ekonomi Universitas Sumatera Utara.

Rawdhyfa, NR. 2018. Pengaruh Gaya Kepemimpinan, Budaya Organisasi Dan Komitmen Organisasi Terhadap Kinerja Manajerial Dan Partisipasi Anggaran (Studi pada BKD Yogyakarta dan BKD Paser). Skripsi. Fakultas Ekonomi. Universitas Islam Indonesia. Yogyakarta

Rezeki, MS. 2017. Pengaruh Partisipasi Penyusunan Anggaran, Komitmen Organisasi Dan Motivasi Kerja Terhadap Kinerja Manajerial Pada Bank Sumut Cabang Kisaran. Skripsi Sarjana. Departemen Akuntansi. Universitas Sumatera Utara 
Sugiyono. 2013. Metode Penelitian Kuantitatif, Kualitatif, dan R\&D. Alfabeta, Bandung.

Triseptya, GN. 2017. Pengaruh Partisipasi Anggaran, Komitmen dan Budaya Organisasi Terhadap Kinerja Manajerial Dengan Gaya Kepemimpinan Sebagai Moderasi. Journal of Management \& Business. 1 (1)

West, M.A. 2009. Mengembangkan Kreativitas dalam Organisasi, Edisi Pertama, Yogyakarta: Kanisius.

Wibowo. 2013. Budaya Organisasi: Sebuah Kebutuhan untuk Meningkatkan Kinerja Jangka Panjang, Jakarta: Rajawali Pers. 